\title{
Kapitalisme, Patriarki dan Globalisasi: Menuju Langgengnya Kekerasan Berbasis Gender Online
}

\author{
Ina Yosia Wijaya, Lidya Putri Loviona* \\ Fakultas IImu Sosial dan Ilmu Politik, Universitas Gadjah Mada \\ ${ }^{\star}$ Penulis Koresponden: Tidyaputriloviona@gmail.com
}

\section{ABSTRAK}

Tulisan ini_-dengan merujuk kepada tema besar "Kekerasan Gender Berbasis Online di Era Pandemi”—mencoba memaparkan bagaimana kontribusi sistem kapitalisme, budaya patriarki, dan globalisasi dalam mendukung lestarinya kekerasan gender secara daring yang sedang marak terjadi di tengah pandemi. Temuan pada tulisan menunjukkan bahwa sistem kapitalisme memegang peranan kunci dalam mendorong terciptanya budaya patriarki dan globalisasi, yang pada akhirnya mendorong langgengnya kekerasan berbasis gender. Berangkat dari perspektif marxist-feminism dengan premis utama bahwa sistem kapitalisme melakukan aksi eksploitasi atas kaum proletar dengan melegalkan segala cara termasuk membangun kesadaran palsu-false consciousness, temuan pada tulisan akan dielaborasikan lebih lanjut melalui tiga bahasan utama. Pertama, akan dipaparkan temuan bahwa opresi terhadap kaum wanita di tengah lingkungan yang patriarki merupakan salah satu upaya manifestasi elit kapitalis untuk melanggengkan sistem kapitalisme. Kedua, komodifikasi wanita_-seperti isu human trafficking-dipercaya sebagai konsekuensi dari sistem kapitalis yang memberikan kebebasan komodifikasi atas segala sumber daya. Terakhir, akan dipaparkan fenomena globalisasi-sebagai salah satu produk liberalisme-kapital-yang dipercaya telah mendorong masifnya aksi human trafficking berbasis daring. Pada akhirnya, melalui temuan dan bahasan terkait kapitalisme sebagai sistem kunci yang telah melanggengkan kekerasan berbasis gender, diharapkan akan muncul kesadaran publik sehingga muncul aksi emansipasi dalam mendorong runtuhnya sisi eksploitatif sistem kapitalisme secara umum dan kekerasan berbasis gender secara khusus.

Kata Kunci: Kapitalisme; Patriarki; Globalisasi; Marxis-Feminis; Kekerasan Gender

\section{ABSTRACT}

This paper-referring to the big theme of "Online-Based Gender Violence in the Pandemic Era"-tries to explain the contribution of the capitalist system, patriarchal culture, and globalization in supporting the sustainability of genderbased violence that is currently rife in the midst of a pandemic. The findings in this paper show that the capitalist system plays a key role in encouraging the creation of a patriarchal culture and globalization, which in turn encourages the perpetuation of gender-based violence. Departing from the perspective of marxist-feminism with the main premise that the capitalist system exploits the proletariat by legalizing all means, including building false consciousness, the findings in this paper will be further elaborated through three main topics. First, the findings will be presented that the oppression of women in a patriarchal environment is one of the manifestations of the capitalist elite to perpetuate the capitalist system. Second, the commodification of women-such as the issue of human trafficking - is believed to be a consequence of the capitalist system that provides freedom for the commodification of all resources. Finally, we will describe the phenomenon of globalization-as one of the products of capitalliberalism - which is believed to have encouraged the massive action of online-based human trafficking. In the end, through findings and discussions related to capitalism as a key system that has perpetuated gender-based violence, it is hoped that public awareness will emerge so that emancipation actions emerge in encouraging the collapse of the exploitative side of the capitalist system in general and gender-based violence in particular.

Kata Kunci: Capitalism; Patriarchy; Globalisation; Marxist-Feminist; Gender Violence

\section{PENDAHULUAN}

Pergerakan dengan tuntutan atas aksi kekerasan berbasis gender telah menjadi diskursus untuk waktu yang cukup lama. Kesadaran akan eksistensi kekerasan berbasis gender dan perlawanan 
terhadapnya pertama kali dilakukan oleh 15.000 perempuan di New York, Amerika Serikat pada tahun 1908. Aksi demonstrasi ini bertujuan untuk menyuarakan hak mereka — para wanita —atas peningkatan standar upah serta pemangkasan jam kerja (CNN, 2021). Penyebarluasan informasi mengenai aksi demonstrasi ini telah mendorong aksi serupa dilakukan oleh wanita di berbagai negara di belahan dunia, hingga pada era perang dunia kedua, tanggal 8 Maret dijadikan masyarakat dunia sebagai momentum penanda advokasi kesetaraan gender. Hal ini kemudian mendorong Perserikatan Bangsa-Bangsa, pada 1975, meresmikan tanggal 8 Maret sebagai International Women's Day (CNN, 2021).

Berbagai aksi tersebut kemudian memunculkan justifikasi dari kaum wanita sendiri dengan mengusung narasi bahwa ketidaksetaraan dan kekerasan yang menimpa wanita merupakan bentuk pelanggaran Hak Asasi Manusia (HAM). Hal ini kemudian mendorong munculnya kelompok antitesis yang menggerus narasi tersebut dengan pandangan bahwa kekerasan dan pelanggaran terhadap HAM dapat menimpa siapa saja tanpa memandang gender nya, sehingga yang perlu menjadi perhatian adalah tindak pelanggaran HAM-nya bukan siapa subjeknya sehingga tuntutan wanita atas isu kesetaraan gender masih diremehkan. Meskipun pelanggaran terhadap HAMseperti yang telah dikemukakan kelompok antitesis-dapat menimpa siapa saja tanpa pertimbangan gender, namun berbagai opresi yang dialami oleh wanita memiliki karakteristik khusus yang serupa. Para wanita menerima tindak opresi, marginalisasi, eksploitasi dan komodifikasi karena "status-nya" sebagai wanita sehingga, pelanggaran HAM wanita yang berkaitan dengan statusnya sebagai wanita memerlukan analisis khusus yang terpisah dari pengkajian jenis pelanggaran HAM lainnya (Rico, 1997: 7).

Meskipun pergerakan para wanita telah terjadi semenjak 1908, hari ini, pergerakan para wanita masih tetap berlangsung karena tuntutan-tuntutan atas isu kesetaraan gender masih belum terpenuhi pada beberapa negara. Jika merujuk pada fakta historis dimana tuntutan wanita cenderung berkaitan dengan kesetaraan posisi pada sektor politik dan ekonomi, tentu dapat dikatakan bahwa isu ini telah menemukan titik temunya. Dapat dibuktikan melalui pencapaian beberapa wanita atas posisi sebagai pimpinan perusahaan ataupun keterlibatan pada pemerintahan serta eksistensi aturan sistem demokrasi yang mensyaratkan persentase tertentu keterlibatan wanita dalam pemerintahan suatu negara. Pada praktiknya, pemenuhan atas tuntutan wanita ini tetap diikuti dengan terjadinya pelanggaran HAM terhadap wanita namun melalui cara baru, salah satunya yang marak hari ini adalah kekerasan berbasis gender yang terjadi secara daring.

Data dari UN Women (2021) beberapa waktu belakang menunjukkan bahwa telah terjadi peningkatan panggilan ke saluran bantuan kekerasan dalam rumah tangga di banyak negara semenjak penyebarluasan virus COVID-19. Selain itu, kebijakan restriksi perjalanan yang menyebabkan masyarakat cenderung menghabiskan waktu di rumah, telah mengakibatkan 1 dari 3 wanita di dunia mengalami kekerasan baik fisik maupun seksual oleh pasangan intimnya (UN Women, 2021). Menanggapi hal tersebut, dibutuhkan analisis, pengkajian serta tindakan kolektif yang melibatkan berbagai pihak sesegera mungkin dalam rangka menanggapi isu kekerasan berbasis gender selama pandemi. Kedua isu konvensional tersebut bukan merupakan isu satusatunya berkaitan dengan kekerasan berbasis gender yang dihadapi di tengah crisis menghadapi pandemi. Transformasi kehidupan masyarakat ke dunia maya dengan frekuensi yang lebih besar dari sebelumnya, telah kembali mengusung atau menciptakan dimensi baru dari kekerasan berbasis gender seperti sexting, harassment, stalking, membagikan konten tanpa konsen dan human trafficking. Poin terakhir-trends human trafficking-telah mengalami peningkatan dalam 
pemanfaatan teknologi sebagai instrumen perwujudannya. Di Amerika Serikat, melalui sebuah penelitian, ditemui fakta bahwa pasca kebijakan restriksi diterapkan, terjadi peningkatan kuantitas pada sex trafficking advertisement di setiap kota yang diamati (Coxen et. al, 2021). Sementara di Inggris, terjadi peningkatan penggunaan adult service websites (ASWs) oleh independent sex workers dalam melakukan iklan atas jasa yang ditawarkannya (Brouwers \& Herrmann, 2020). Dengan merujuk kepada peran teknologi dalam perkembangan dimensi kekerasan berbasis gender, kekerasan gender secara daring dapat dilihat sebagai konsekuensi negatif dari globalisasi. Maka, kapitalisme, sebagai konsepsi yang mendorong lahirnya globalisasi serta privatisasi, menyebabkan kelompok yang bukan merupakan pemilik alat produksi secara tidak sadar dipaksa untuk menerima jenis pekerjaan apapun untuk bertahan hidup yang mendorong kontribusi atas lestarinya kekerasan berbasis gender-khususnya online.

Secara lebih lanjut, tulisan ini akan menganalisis bagaimana relasi antara eksistensi dari sistem kapitalisme dengan kekerasan berbasis gender secara daring. Dengan mengupas berbagai diskursus, mistifikasi serta konstruksi yang telah melanggengkan eksistensi kekerasan berbasis gender daring dalam rangka penemuan jawaban atas rumusan masalah yang diajukan, diharapkan penelitian yang dituangkan melalui tulisan ini dapat memberikan solusi atas eksistensi dan perkembangan kekerasan berbasis gender secara daring. Pada bagian selanjutnya dari tulisan ini, dalam melakukan eksplorasi untuk menemukan jawaban dari rumusan masalah yang telah diajukan, penulis akan berfokus kepada salah satu isu kekerasan berbasis gender daring, yaitu isu sex trafficking dengan limitasi waktu selama pandemi dengan mempercayai bahwa sistem kapitalisme - melalui relasi positifnya dengan tatanan yang patriarki serta melalui konsekuensi yang diciptakan dari konsepsi pasar bebas yang lekat dengan terma globalisasi-memiliki andil dalam kehadiran dan langgengnya kekerasan berbasis gender secara daring.

Pandangan demikian akan dielaborasikan lebih lanjut melalui tiga argumen pendukung. Pertama, bahwa opresi terhadap kaum wanita di tengah lingkungan yang patriarki merupakan salah satu manifestasi elit kapitalis untuk melanggengkan sistem kapitalisme. Kedua, Komodifikasi wanitaseperti isu human trafficking - dipercayai sebagai konsekuensi dari sistem kapitalis yang memberikan kebebasan komodifikasi atas segala sumber daya. Ketiga, fenomena globalisasisebagai salah satu produk liberalisme-kapital_telah mendorong masifnya aksi human trafficking berbasis daring.

\section{TINJAUAN PUSTAKA}

Pemahaman yang berkembang di masyarakat mengenai terma "kapitalisme" seringkali didefinisikan sebagai sebuah sistem ekonomi yang mampu mentransformasi dan memfasilitasi pertumbuhan ekonomi berkelanjutan. Namun, dalam praktiknya, kapitalisme tidak hanya sebatas sistem ekonomi yang identik dengan pertumbuhan dan keberlanjutan, Werlhof dalam jurnal bertajuk "No critique of capitalism without a critique of patriarchy! Why the left is no alternative" juga menggarisbawahi pentingnya sistem kapitalisme untuk mencapai bentuk produksi komoditas dengan biaya semurah mungkin (Von Werlhof, 2007: 15). Pada kenyataannya, upaya penekanan biaya produksi oleh sistem kapitalisme sering kali melegalkan berbagai hal-tidak terkecuali upaya komodifikasi terhadap dimensi "natural" dari aspek sosial-geografi. Sebagai sebuah sistem, kapitalisme menawarkan dua gagasan utama, yaitu: 'privatisasi alat produksi'_yang memungkinkan mendorong terbentuknya dikotomi antara pemilik alat produksi dan pekerja yang sekaligus menjadi basis dari eksploitasi-; serta 'pasar bebas' — dengan potensi mendorong 
terjadinya komodifikasi alam (Wisman, 2014: 1). Berangkat dari gagasan tersebut, eksploitasi upah, waktu dan tenaga buruh, degradasi lingkungan, serta komodifikasi alam termasuk budaya dan manusia menjadi serangkaian isu yang terlibat dalam diskursus sistem kapitalisme dan perlu untuk dikaji lebih lanjut. Fakta-fakta komodifikasi aspek sosial-geografi oleh sistem kapitalisme ini salah satunya telah dibongkar oleh Collin C. William dalam bukunya "A Commodified World: Mapping the Limits of Capitalism".

Melalui uraian di atas, terlihat bagaimana kapitalisme memiliki peran atas eksistensi kekerasan berbasis gender. Gagasan yang diusung oleh sistem kapitalisme telah-sedikit banyakberkontribusi terhadap berbagai opresi yang menimpa wanita. Dengan merujuk kepada konteks sejarah perjuangan wanita, Enloe dalam pemaparannya pada sebuah interview "Bananas: Cynthia Enloe" menggambarkan bagaimana stigma bahwa wanita berhak digaji lebih rendah daripada lakilaki (underpaid) menjadi isu yang terjustifikasi melalui studi kasus sebuah Banana Industry di Amerika Latin. Stigma demikian dijustifikasi dengan merujuk kepada pandangan bahwa wanita merupakan unskilled labour dan memiliki suami yang membiayainya (Enloe, 2015). Jika ditelisik lebih lanjut, kekerasan dan eksploitasi yang dialami wanita pada Banana Industry tersebut merupakan salah satu manifestasi pemilik faktor produksi - sebagai pihak yang diuntungkan oleh sistem kapitalisme - untuk mengupayakan produksi komoditas dengan biaya minimum. Pada masa kontemporer ini-ketika partisipasi wanita dalam sektor ekonomi dan politik mulai dipertimbangkan, kontribusi sistem kapitalisme terhadap isu kekerasan terhadap wanita hadir melalui dimensi yang berbeda, salah satunya perdagangan wanita (sex trafficking) yang akan dikaji pada bagian selanjutnya dari tulisan ini. Merujuk kepada relasi antara kapitalisme dan kekerasaan terhadap wanita seperti yang telah dijabarkan di atas, penulis melihat pentingnya mengkaji patriarki dan kapitalisme sebagai dua terma yang saling mempengaruhi.

Dalam penelitian bertajuk "How do patriarchy and capitalism jointly reinforce the oppression of women?" Camille Bruneau telah memaparkan berbagai fakta historis yang menunjukkan relasi antara lingkungan yang dibaluti stigma patriarki dengan sistem kapitalisme. Meskipun konsep "kebebasan" dalam sistem kapitalisme telah memberi ruang bagi wanita untuk menyuarakan kepentingannya, namun menurut Bruneau, patriarki-yang dicirikan dengan penindasan dan marginalisasi yang dialami wanita karena statusnya sebagai perempuan di lingkungan yang sebagian besar kekuasaan didominasi oleh laki-laki - memiliki relasi "saling menguntungkan" dengan sistem kapitalisme dalam upaya mempertahankan keberlanjutan eksistensi keduanya (Bruneau, 2021).

Di sisi lain, globalisasi sebagai salah satu konsekuensi dari konsep pasar bebas pada sistem kapitalisme, turut memiliki andil dalam perkembangan kekerasan terhadap wanita. Permintaan dan penawaran wanita-sex trafficking-yang tidak dilegalkan hukum, sering memanfaatkan perkembangan teknologi seperti platform social media dan website dalam transaksinya. Pemanfaatan teknologi dalam upaya komodifikasi wanita ini mengalami peningkatan kuantitas pasca penyebarluasan virus COVID-19. Penelitian bertajuk "COVID-19 pandemic's impact on online sex advertising and sex trafficking" oleh Coxen, Castro, Carr, Bredin dan Guikema menjadi pendukung pandangan ini dengan memaparkan bagaimana teknologi telah berkontribusi dalam peningkatan kekerasan terhadap wanita berbasis online selama pandemi-khususnya berkaitan dengan isu sex trafficking advertising — dengan studi kasus Amerika Serikat (Coxen et. al, 2021).

Berangkat dari fakta minimnya hukum legal yang mengatur aktivitas dunia maya serta sulitnya mendeteksi pelanggaran hukum yang dilakukan secara online, penulis menilai isu kontemporer 
berkaitan dengan kekerasan berbasis gender yang mengambil tempat pada dunia maya merupakan pembahasan yang krusial. Mengingat peran penting fenomena globalisasi dalam isu ini, maka pembahasannya tidak dapat dipisahkan dari asumsi-asumsi kapitalisme yang berkembang sebagai cikal bakal dari globalisasi, serta terma patriarki yang memiliki relasi positif dengan kapitalisme. Dengan demikian, tulisan ini akan membongkar fakta-fakta dibalik perkembangan kekerasan berbasis gender online dengan mengacu pada tiga terma utama, yaitu: Kapitalisme; Patriarki; dan Globalisasi. Dalam proses perumusan hasil penelitian ini, penulis menemukan sedikit kesulitan dalam memperoleh data untuk diolah mengingat limitasi waktu yang diajukan atas topik berkaitan relatif baru, sehingga hanya terdapat sedikit penelitian dan basis data yang membahas mengenai isu ini. Selain itu, belum terbongkar dan dilaporkannya berbagai fakta serta fenomena yang berkaitan dengan isu yang diangkat dalam tulisan ini, turut menjadi tantangan dalam pengumpulan data. Pada akhirnya, tulisan ini cenderung menggunakan pendekatan historis dalam pengkajiannya serta tidak mengabaikan peran krusial dari fakta dan data — pemaknaan terhadap data.

\section{KERANGKA PIKIR DAN METODOLOGI}

Kekerasan gender berbasis online dan relasinya dengan kelestarian sistem kapitalisme dalam tulisan ini akan penulis lihat melalui kacamata teori Marxis-Feminis yang merupakan bagian dari kritik terhadap sistem yang kapitalis serta budaya patriarki yang menyudutkan perempuan dalam berbagai tatanan di dalam kehidupan masyarakat. Teori Marxis-Feminis merupakan turunan dari teori Marxis yang menggolongkan masyarakat menjadi dua kelas, yaitu borjuis dan proletar. Penggolongan ini didasarkan pada kepemilikan modal di dalam pasar. Kaum proletar adalah orangorang yang tidak memiliki modal sedangkan kaum borjuis merupakan kelompok orang-orang yang mempunyai modal dan bahkan mempunyai kuasa di dalam pasar, sehingga fenomena yang menjadi perhatian Marx adalah eksploitasi yang dilakukan oleh kaum borjuis kepada kaum proletar (Marx, 1976). Sistem yang menjustifikasi kaum borjuis melakukan eksploitasi atas kelompok proletar kemudian dikenal dengan istilah kapitalisme. Menurut Marx, kapitalisme melegalkan segala cara termasuk membangun kesadaran palsu-false consciousness - bagi kaum proletar sehingga dapat dengan mudah dieksploitasi (Lukács, 1972).

Di sisi lain, teori feminisme merupakan kerangka berpikir yang mendasari pemikiran mengenai pemberdayaan wanita. Teori ini muncul pertama kali pada abad ke-19 sebagai kritik dari adanya sistem politik internasional yang mengedepankan peran pengaruh laki-laki pada kegiatan politik yang "maskulin"- perang, militer, dan senjata. Penganut teori ini berpendapat bahwa dalam sistem politik internasional, perempuan juga bisa memberikan dampak politik seperti yang terjadi dengan aktris keturunan Latin, Carmen Miranda (Enloe, 2014). Pada tahun 1930-an, karir Carmen Miranda melejit sehingga ia mendapatkan kesempatan untuk pergi ke Hollywood yang membuatnya semakin terkenal. Dengan melejitnya karir Carmen Miranda, Amerika Latin kemudian juga mulai mendapatkan rekognisi dari negara-negara besar seperti Amerika Serikat sehingga menyebabkan konstelasi politik internasional masa itu berubah (Enloe, 2014). Peristiwa ini membuktikan bahwa perempuan juga bisa memberikan partisipasi penting dalam tatanan politik internasional sehingga seharusnya tidak ada entitas yang tidak diberi ruang untuk terlibat ke dalam sistem sosial politik.

Engels meminjam teori Marx untuk memberikan pandangan yang lebih luas bagaimana sistem yang ada di masyarakat menyudutkan perempuan. Dalam karyanya yang berjudul "The Origins of Family, Private Properties, and the State” ia memaparkan alasan-alasan mengapa perempuan yang 
tidak memiliki modal — proletar — termarjinalkan di dalam sistem yang ada di masyarakat. Secara garis besar, isi buku ini menggambarkan bahwa sejak masa prasejarah peran perempuan tidak terlalu direkognisi dan perempuan tidak diberi ruang dalam kegiatan perburuan dan pembuatan senjata karena dianggap memiliki tenaga yang lebih sedikit daripada kaum laki-laki, sehingga akan lebih baik bila kaum perempuan melakukan tugas rumah-memasak, mengurus anak, mencuci, dan kegiatan "feminim" lainnya (Engels, 1978). Pemahaman ini yang kemudian menjadi dasar dari sistem patriarki yang 'eksis' di dalam masyarakat.

Masa industrialisasi kemudian menjadi titik temu antara budaya patriaki dan sistem kapitalis yang semakin mengopresi kedudukan wanita. Masa industrialisasi membuat kegiatan produksi berkembang dengan pesat dalam jumlah yang masif, sehingga membutuhkan banyak tenaga kerja yang murah untuk kelangsungan kegiatan produksi. Kaum wanita pada masa itu menjadi sasaran empuk untuk dijadikan sebagai "budak" mengingat budaya patriarki pada masa itu meremehkan keberadaan perempuan sehingga upah wanita sebagai buruh lebih rendah daripada upah pria (Engels, 1978). Selain itu, dengan adanya sistem kapitalis yang merekrut perempuan sebagai tenaga kerja dianggap sebagai jalan keluar untuk menyetarakan posisi antara wanita dan priaperempuan dapat memperoleh penghasilan tanpa bergantung kepada suaminya - karena di masa ini perempuan tidak diijinkan untuk mempunyai aset sehingga perempuan hanya dapat "menikmati" aset dari laki-laki yang kemudian menyebabkan perlakuan kaum lelaki kepada perempuan menjadi sesuka hati (Engels, 1978). Perempuan juga diproyeksikan sebagai pencipta faktor produksi bagi sistem kapitalis - yaitu melalui reproduksi anak. Kekerasan terhadap perempuan tidak berhenti sampai disini, selanjutnya sistem kapitalis juga menunggangi sikap rasisme yang menyebabkan masifnya perbudakan kepada wanita Afrika dan Amerika Latin pada abad ke-19 (Engels, 1978).

Kajian-kajian mengenai Marxis-Feminis pada dasarnya membantu membongkar dan memberikan pemahaman lebih mendalam mengenai sistem yang memojokkan perempuan, seperti praktik kapitalisme yang menunggangi sikap rasisme - dalam buku milik Engel-dan budaya patriarki sehingga dapat memberikan gambaran yang lebih jelas mengenai apa yang melatarbelakangi opresi kepada kaum perempuan (Stefano, 2014). Dengan adanya fusi dari perspektif Marxisme dan Feminisme, kekerasan berbasis gender dapat dianalisis ke dalam ruangan yang lebih luas sehingga memungkinkan bagi penyintas kekerasan berbasis gender untuk mendapatkan solusi yang dapat menyelesaikan masalah ini hingga ke "akarnya". Sebelum adanya fusi antara kedua diskursus ini, pemberdayaan perempuan yang tertindas budaya patriarki adalah dengan menggunakan sistem kapitalisme (Stefano, 2014). Namun hasilnya, perempuan malah makin terpojokkan sehingga Engel melihat bahwa kapitalisme bukan merupakan solusi dari budaya patriarki, yang ada malah semakin memarjinalkan perempuan dalam sistem ekonomi.

Penulis meyakini bahwa kerangka teori dari Marxis-Feminis dapat juga memberikan gambaran yang lebih luas mengenai kekerasan gender berbasis online karena pada dasarnya kekerasan gender berbasis online adalah bentuk digital dengan metode daring dari kekerasan gender yang selama ini telah ada di dalam diskusi-diskusi pemberdayaan wanita. Perbedaan yang mendasar dari kekerasan gender berbasis online atau offline adalah bahwa pada kekerasan gender berbasis online memanfaatkan perkembangan teknologi yang memungkinkan banyaknya korban dan minimnya riset terhadap fenomena ini (World Bank, 2021). Selain dari perbedaan itu, penulis, tidak melihat perbedaan motivasi dari pelaku dan juga proyeksi "korban" dari adanya kekerasan gender berbasis online ini. Penulis juga merasa bahwa bergabungnya sistem yang kapitalis dan budaya patriarki 
ditambah dengan masifnya penggunaan teknologi untuk melangsungkan kekerasan semakin memberikan ruang untuk mendorong langgengnya kekerasan gender.

Kemudian, dengan mempertimbangkan fenomena kekerasan gender berbasis online yang lebih sering dinumerikan, penulis memilih untuk menginterpretasikan lebih jauh fenomena kekerasan berbasis gender secara daring. Dalam hal ini penulis akan menggunakan metode kualitatif yang mengedepankan pemahaman secara mendalam terhadap sebuah realitas sosial. Metode penelitian kualitatif pada dasarnya merupakan metode yang memberikan pemaknaan terhadap realitas di dalam fenomena yang sedang dikaji. Objek yang menjadi kajian untuk metode ini adalah tingkah laku dari para aktor yang terlibat sehingga dapat memberikan interpretasi khusus bagi para peneliti dalam melihat sebuah kasus spesifik. Metode kualitatif memungkinkan penggunanya untuk menggunakan data berupa angka, namun peneliti berusaha untuk membongkar konteks yang ada di belakang angka tersebut. Dalam mengumpulkan data, kami menggunakan metode studi kepustakaan melalui artikel jurnal, buku, serta artikel berita daring. Metode penelitian kualitatif membutuhkan kedekatan antara peneliti dan objek penelitiannya sehingga posisi penulis dalam penelitian ini tidak jauh dari objek kajian, agar dapat memberikan pemaknaan yang lebih mendalam mengenai kekerasan gender berbasis online serta dapat semakin menambah akurasi dari data yang kami berikan.

Metode kualitatif di dalam penelitian sering juga disebut dengan studi kasus. Gerring dalam tulisannya memaknai studi kasus sebagai studi yang intensif mengenai sebuah kasus khusus yang bertujuan untuk memberikan pemahaman kepada audiens sehingga kasus tersebut dapat mengalami eksplorasi yang lebih dalam dari sisi-sisi selain data yang disajikan secara numerik (Gerring, 2004). Metode ini relatif digunakan bagi peneliti yang mengedepankan kedalaman daripada keluasan data dalam mempelajari sebuah kasus sehingga alasan lain bagi penulis untuk menggunakan metode ini adalah karena penulis menginginkan eksplorasi yang lebih mendalam mengenai realitas kekerasan berbasis gender online yang juga mendapatkan pengaruh dari langgengnya sistem kapitalisme (Gerring, 2004).

\section{HASIL DAN PEMBAHASAN}

Kekerasan gender berbasis online menjadi salah satu masalah yang pelik dan menjadi perhatian bagi para penyintas kekerasan gender dalam sistem sosial di era pandemi seperti sekarang ini, karena kegiatan manusia hampir secara sempurna dilaksanakan secara daring. Dalam penelitian yang dilakukan oleh GenderIT, fakta mengejutkan diperoleh, yaitu bahwa selama pandemi kekerasan gender baik yang berbasis online maupun secara fisik mengalami peningkatan yang signifikan (Bondy, 2020). Dampak yang ditimbulkan dari adanya peningkatan kekerasan gender berbasis online adalah rasa insekuritas bagi para wanita yang dapat mengganggu kegiatan mereka karena bentuk dari kekerasan gender berbasis online memiliki banyak bentuk dan pelakunya semakin "kreatif" dalam merundung targetnya (Bondy, 2020). .Bentuk-bentuk umum dari kekerasan gender berbasis online adalah sexting, harassment, stalking, membagikan konten tanpa konsen, dan berbagai bentuk lainnya yang berkembang seiring dengan majunya teknologi.

Asumsi sederhana dari peningkatan yang cukup signifikan ini adalah bahwa tingkat stress masyarakat meningkat karena pandemi memberi "batasan" bagi segala kegiatan kehidupan manusia. Namun, bila asumsi tersebut ditarik menuju konsep yang lebih luas untuk memberikan pemahaman yang lebih mendalam mengenai kekerasan gender berbasis online, secara sederhana konsep yang kami ajukan adalah afiliasi sistem kapitalis dengan segala aspek kehidupan manusia. 
Sistem kapitalis dalam Werlhof(2007), yang memprivatisasi sumber daya, menuntut manusia yang ada dalam sistem kapitalis untuk bekerja demi mendapatkan uang-kapital_untuk mempertahankan kelangsungan kehidupannya. Masa pandemi membuat beberapa lapisan masyarakat harus mengalami kesulitan secara finansial sehingga untuk mempertahankan hidup mau tidak mau harus memutar otak, mencari cara yang kreatif untuk dapat mempertahankan hidup. Salah satu cara termudah untuk mendapatkan sokongan finansial tersebut adalah dengan menjual konten tanpa konsen atau bahkan secara sederhana tetap menerima perlakuan kekerasan demi mendapatkan uang (Werholf, 2007). Konsep sederhana inilah yang menjadi dasar dari argumen kami bahwa sistem kapitalis membantu kelestarian kekerasan gender berbasis online.

Pertama, tulisan ini meyakini bahwa sistem kapitalis tidak independen dalam mengambil bagian untuk melanggengkan kekerasan gender berbasis online. Ada faktor lain yang juga turut berpartisipasi dalam sistem kapitalis untuk melanggengkan kekerasan gender berbasis online. Bila ditelisik, secara umum, terma kekerasan gender muncul karena adanya sistem yang yang menyebabkan salah satu gender menerima perlakuan diskriminasi. Budaya patriarki kemudian menjadi salah satu rujukan yang menjadikan kekerasan berbasis gender terhadap wanita dapat termanifestasikan secara sempurna dalam realitas sosial. Budaya ini memberikan legitimasi penuh kepada laki-laki untuk memperlakukan wanitanya — istrinya atau selirnya — sesuka hati karena budaya ini memberi persepsi bahwa posisi pria berada di atas wanita, yaitu patriarki (Engels, 1978). Dari tinjauan historis, budaya patriarki telah ada jauh sebelum sistem kapitalis mengambil tempat dalam kehidupan ekonomi masyarakat dunia. Engels (1978), dalam bukunya, merefleksikan bahwa adanya sistem yang menomorduakan posisi wanita dipengaruhi dari zaman peradaban manusia yang memberikan segregasi pekerjaan berdasarkan gender. Kemudian seiring dengan perkembangan zaman, budaya patriarki berafiliasi dengan sistem kapitalisme yang menyebabkan wanita di dalam kelas proletar mengalami tingkat opresi yang tinggi. Sejalan dengan pemikiran Engels, Burris (1982) dalam tulisannya turut memaparkan bahwa patriarki turut membantu langgengnya sistem kapitalis dengan memberikan fungsi kepada wanita sebagai pencipta sumber daya bagi elit kapitalis - dengan melahirkan anak. Praktik-praktik afiliasi dari sistem kapitalis dengan budaya patriarki digambarkan dengan jelas dalam praktik perbudakan yang dialami oleh wanita Afrika dan Amerika Latin pada abad ke-16 (Burris, 1982). Bila menggunakan teori MarxisFeminis sebagai kacamata untuk melihat realitas ini adanya budak wanita dengan upah rendah merupakan manifestasi nyata dari keberadaan sistem kapitalisme bersama dengan budaya patriarki dan juga tidak lupa rasisme yang mengopresi wanita. Tidak hanya berhenti di sini, adanya 'perbudakan' bagi wanita kemudian tidak semata-mata berhenti dengan selesainya masa perbudakan. 'Perbudakan' wanita mengalami transformasi bentuk, seperti dalam kasus sextrafficking yang ditulis oleh Coxen dan juga Cruz (Coxen et. al, 2021; Cruz, 2018: 65). Dengan adanya kedua kasus ini, kami melihat bahwa budaya patriarki memberikan legitimasi terhadap sistem kapitalis untuk melanggengkan sistemnya melalui tuntutan-tuntutan untuk melangsungkan kehidupan_-dengan mencari sokongan finansial.

Hal yang sama juga terjadi pada kekerasan gender berbasis online yang semakin marak di masa pandemi. Meskipun memiliki bentuk yang berbeda dari kekerasan gender konvensional, kekerasan gender berbasis online masih berkaitan dengan opresi terhadap perempuan dan proyeksi terhadap perempuan sebagai kaum yang 'layak' untuk mendapatkan perlakuan semacam ini-bila menggunakan teori Marxis-Feminis. Pada dasarnya, seperti yang sudah disebutkan sebelumnya, kekerasan gender berbasis online merupakan bentuk digital dari adanya kekerasan gender konvensional sehingga segala jenis latar belakang yang mendasari realitas ini kami argumenkan 
masih sama, yaitu karena adanya pandangan sebelah mata bagi kaum perempuan sebagai bagian dari budaya patriarki. Namun, dampak opresi terhadap perempuan dengan kedua metode yang berbeda, sehingga akibat yang ditimbulkan juga berbeda. Pada kekerasan gender konvensional, akan ditemukan luka-luka secara fisik sedangkan pada kekerasan gender berbasis online tidak akan ditemukan luka-luka secara fisik, namun kesehatan mental dari korban berada di dalam posisi yang tidak aman. Pelaku dari kekerasan gender berbasis online juga lebih sulit ditemukan dan ditangkap daripada pelaku kekerasan gender konvensional, selain karena belum ada basis hukum yang legal untuk memberi efek jera pada pelaku, jejak dari pelaku lebih sulit untuk ditelusuri sehingga pelaku sangat leluasa dalam menjalankan aksinya — karena pelaku mendapatkan uang dari kegiatan ini. Seakan semakin memberikan ruang untuk kekerasan gender berbasis online, sistem kapitalis yang berafiliasi dengan budaya patriarki memberikan pemahaman yang dapat digunakan untuk menjustifikasi sikap ini. Dengan adanya faktor-faktor tersebut kami mengasumsikan kekerasan gender berbasis online akan langgeng dengan dukungan dari sistem kapitalisme dan budaya patriarki. Juga, mengingat kondisi pandemi yang membuat fokus utama manusia adalah untuk mendapatkan uang demi bertahan hidup, kekerasan gender berbasis online kami nilai akan mengambil tempat cukup lama pada isu gender.

Kedua, keyakinan tulisan ini akan kontribusi sistem kapitalisme atas eksistensi dan keberlanjutan kekerasan berbasis gender online, berkaitan dengan diskursus terma "komodifikasi" yang menjadi kritik atas konsepsi kapitalisme. Sejalan dengan pandangan Amin et al. bahwa sistem kapitalisme dengan konsepsi dasar "pasar bebas" yang mendorong terciptanya jangkauan nilai tukar yang meluas, telah menyebabkan sulitnya membayangkan dan melegitimasi bentuk organisasi dan ketentuan yang tergolong kedalam bagian dari non-pasar (Williams, 2005). Kebebasan pada berbagai aspek ini pada akhirnya akan mengakibatkan aksi komersialisasi dan komodifikasi berbagai dimensi natural dari aspek sosial-geografi secara luas dan tanpa batas oleh elit kapitalisme. Komodifikasi sendiri sebagai sebuah terma merujuk kepada proses dimana terjadi peningkatan produksi dan pengiriman barang serta jasa oleh perusahaan kapitalis untuk pertukaran uang dan tujuan memperoleh keuntungan (Williams, 2005). Aksi komodifikasi berbagai dimensi natural dari aspek sosial-geografi dinilai buruk karena telah terbukti bersifat eksploitatif atas aspek-aspek nonkomersial yang telah dikomodifikasi. Hal ini misalnya tergambar dari bagaimana pemanfaatan atas sumber daya secara masif dengan tujuan memperoleh keuntungan-komodifikasi alam — telah berujung kepada kepunahan dan kelangkaan Sumber Daya Alam dan degradasi lingkungan, atau bagaimana komersialisasi pertunjukan seni dan budaya dalam konteks pariwisata—komodifikasi budaya - telah menyebabkan terjadinya disorientasi, dislokasi serta krisis orientasi dari nilai sosial-budaya lokal, atau bagaimana komodifikasi dari pengetahuan melalui eksistensi lembaga bimbingan belajar telah menyebabkan sebagian orang kehilangan hak untuk memperoleh pendidikan, serta juga dapat berkaca melalui kondisi dimana komodifikasi turut dilakukan terhadap manusia melalui isu human trafficking misalnya. Kehidupan yang dibayangkan tanpa aksi komodifikasi merujuk kepada tiga kondisi. Pertama, dimana kehidupan dijalankan dengan metode subsisten atau proses produksi dilakukan untuk kebutuhan pribadi tanpa tujuan melakukan pertukaran atau memperoleh bayaran. Kedua, proses produksi dilakukan dengan terdapat intensi untuk melakukan pertukaran barang dan jasa, namun tidak dibarengi dengan pertukaran uang. Ketiga, bentuk kegiatan non-komodifikasi yang dibayangkan adalah dimana terdapat transaksi monetisasi, namun tidak dibarengi dengan tujuan memperoleh keuntungan (Williams, 2005). Adopsi dari salah satu mekanisme non-komodifikasi yang telah dipaparkan, pada akhirnya akan mendorong setiap orang mendapatkan kesempatan yang sama dalam memenuhi kebutuhan 
hidupnya - karena tidak terdapat privatisasi Sumber Daya—sehingga tidak akan dijumpai berbagai aksi eksploitasi terhadap kelompok yang dikategorikan sebagai bukan pemilik alat produksi. Absennya privatisasi Sumber Daya dan terdapatnya kesempatan yang sama bagi setiap orang untuk memenuhi kebutuhannya, juga dapat berujung pada pengurang jumlah orang yang bekerja tidak atas intensinya melainkan atas tekanan sosial atau ekonomi yang dialaminyamisalnya sex workers.

Seperti telah disebutkan di atas, pada kasus kekerasan berbasis gender, aksi komodifikasi tercermin melalui kasus human trafficking. Dimana dalam kasus ini subjek komodifikasinya adalah manusia-dalam hal ini wanita. Pada kasus human trafficking, aksi komodifikasi atas wanita bukan menjadi satu-satunya isu yang problematis. Jika ditelisik lebih lanjut, intensi dari baik pelaku aksi human trafficking maupun korbannya - dalam hal ini sex workers-dilandasi atas realita yang telah dibentuk tatanan kapitalis. Intensi kedua subjek ini untuk terlibat dalam isu human trafficking disebabkan oleh posisi mereka yang sama-sama bukan sebagai pemilik alat produksi. Di satu sisi, pelaku aksi human trafficking berusaha mencari objek yang dapat dijadikannya sebagai faktor produksi dalam melakukan aksi komodifikasi atasnya — dalam hal ini tubuh para pekerja sex-di sisi lain, keterlibatan pekerja sex dalam isu human trafficking disebabkan oleh keterbatasan mereka atas akses pemenuhan kebutuhan karena tidak memiliki alat produksi, sehingga menjadi sex workers adalah opsi satu-satunya. Hal ini tergambar jelas melalui kondisi di era Pandemi ini. Tekanan dan krisis ekonomi yang telah disebabkan oleh pandemi, mendorong banyak orang yang pada dasarnya tanpa intensi, memilih jalan untuk terlibat sebagai bagian dari korban human trafficking. Pandangan ini sejalan dengan bagaimana telah terjadi peningkatan kuantitas human trafficking advertisement di berbagai website di sebagian besar negara (Coxen et. al, 2021). Dengan berkaca melalui fenomena di atas, penulis yakin bahwa langgengnya kekerasan berbasis gender online turut didorong oleh eksistensi dan perkembangan sistem dan tatanan yang kapitalis.

Ketiga, sebagai akibat dari adanya globalisasi — sebagai salah satu produk liberalisme-kapitalteknologi berkembang dengan pesat yang kemudian menjadi instrumen utama bagi kekerasan gender berbasis online salah satunya kasus human trafficking (Coxen et. al, 2021). Fitur kemajuan teknologi pada globalisasi semakin maju membuat posisi wanita semakin rentan terhadap kekerasan gender. Berdasarkan fakta dari lapangan, kekerasan gender semakin meningkat seiring dengan perkembangan teknologi (Coxen et. al, 2021). Hal ini dapat dimaknai sebagai adanya pemanfaatan teknologi sebagai instrumen utama untuk melakukan kekerasan padahal seharusnya keberadaan internet dapat memberikan fungsi pengawasan dan dapat membantu korban kekerasan gender berbasis online mendapatkan keadilan, namun yang terjadi malah sebaliknya, pelaku seakan diberikan kenyamanan dengan adanya teknologi yang dapat menyalurkan tindakantindakan negatifnya (Suzor et. al, 2019: 85).

Kemudian, dengan mempertimbangkan bahwa globalisasi juga mengurangi batas-batas negara, sosial, dan bahkan ekonomi, kekerasan berbasis gender secara daring kami asumsikan akan semakin langgeng. Fenomena globalisasi yang demikian cepat dan tidak terbatas menuntut semua kalangan masyarakat untuk sama-sama "bertindak cepat" untuk mempertahankan diri. Dalam dimensi ekonomi, untuk mempertahankan eksistensi diri dalam globalisasi negara-bangsa membuka dirinya pada perdagangan bebas yang dekat dengan sistem kapitalisme (Bataka, 2020). Merujuk kembali pada penelitian Coxen et. al (2021), fenomena globalisasi dapat meningkatkan dan mempertahankan human trafficking serta sex advertisement, khususnya dalam masa pandemi 
yang membatasi kegiatan tatap muka antar manusia, klasifikasi sebagai "pelaku" dalam kejahatan ini semakin sulit didefinisikan dan bahkan ditelusuri jejaknya. Oleh karena itu, menurut penulis, kelestarian kekerasan gender secara daring akan semakin diperkuat.

\section{KESIMPULAN DAN REKOMENDASI KEBIJAKAN}

Kekerasan gender berbasis online telah menemukan tempatnya-pada masa pandemi-sehingga praktik kekerasan ini menjadi sangat masif dan banyak dilakukan oleh pelaku-pelaku kekerasan gender. Kekerasan gender sendiri sudah seakan menjadi budaya yang diwariskan dari nenek moyang seluruh masyarakat di dunia. Secara historis, hal ini dipengaruhi oleh adanya segregasi pekerjaan berdasarkan gender yang dimulai pada masa pra-sejarah. Secara sederhana dapat dipahami bahwa, semakin maraknya perkembangan industri, kebutuhan akan sumber daya juga semakin meningkat. Hal ini kemudian menyebabkan perempuan yang berada di bawah posisi kaum laki-laki menerima opresi. Sepanjang sejarah mencatat, suara emansipasi untuk kaum perempuan dimulai pada tahun 1908 di Amerika Serikat. Adanya gerakan ini kemudian memicu munculnya diskusi-diskusi dan berbagai macam diskursus yang merekognisi peran perempuan dalam sistem sosial-politik-ekonomi masyarakat. Dengan munculnya berbagai macam diskusi dan diskursus mengenai peran perempuan lantas tidak mengeliminasi kekerasan gender yang ada, malahan kekerasan gender bersama dengan teknologi membentuk sebuah sistem kekerasan baru, yaitu berbasis daring. Hal ini yang kemudian menjadi perhatian utama penulis di dalam tulisan ini. Menggunakan kajian Marxis-Feminis, kekerasan gender berbasis online menurut penulis merupakan salah satu manifestasi nyata dari adanya sistem kapitalis yang berfusi dengan budaya patriarki yang turut menumpang pada globalisasi, juga merupakan salah satu instrumen bagi sistem kapitalisme untuk mempertahankan eksistensinya. Era pandemi seperti sekarang ini juga seakan memberikan momentum bagi kelestarian kekerasan gender berbasis online dengan menciptakan "keterbatasan" bagi beberapa masyarakat tertentu yang kemudian mendorong manusia untuk "menghalalkan" berbagai macam cara agar bertahan hidup.

Untuk menghentikan siklus kekerasan gender berbasis online penulis memberikan rekomendasi berupa saran bagi pemerintah, yaitu untuk menetapkan suatu basis hukum yang jelas agar memberikan efek jera bagi pelaku kekerasan gender berbasis online. Mengingat pula bahwa isu ini merupakan isu baru di dalam tatanan sosial masyarakat, basis hukum untuk mempidanakan pelaku dari kekerasan ini sangat diperlukan. Sebagai contoh, seharusnya pemerintah mengesahkan RUU PKS yang sempat menduduki puncak isu di Indonesia sehingga keberadaan RUU PKS dapat menjadi suatu basis hukum yang jelas atas tindakan kekerasan pelaku. Selain itu, proses pembuatan kerangka hukum legal atas kegiatan berbasis daring perlu melibatkan wanita yang mampu menyuarakan kepentingan setiap wanita, agar kerangka hukum yang dibentuk dapat mewakili suara wanita sebagai subjek yang mendapatkan opresi dalam kasus ini. Pemerintah juga perlu menciptakan rancangan pengawasan yang sistematis untuk dunia maya, mengingat hari ini hampir sebagian besar kehidupan dan interaksi masyarakat dilaksanakan berbasis daring. Berkaitan dengan kontribusi sistem kapitalisme dalam isu ini, penulis merekomendasikan pemerintah untuk melakukan sedikit intervensi atas konsepsi kebebasan yang diusung sistem kapitalis agar tidak terjadi eksploitasi dan komodifikasi yang meluas dan tanpa batas atas produk non-komersial. Selain itu, transformasi alat-alat produksi-common goods-yang telah diprivatisasi menjadi kepemilikan negara dirasa perlu, dalam rangka memastikan setiap individu mendapatkan akses yang sama dalam pemenuhan kebutuhan hidupnya dan pada akhirnya tidak akan ada lagi individu yang melakukan pekerjaan tanpa intensinya untuk melakukan pekerjaan tersebut. 


\section{DAFTAR PUSTAKA}

Artikel Daring

Bondy, H., 2020. Feminist talk. [daring] GenderIT.org. Dapat diakses di: $<$ https://www.genderit.org/feminist-talk/domestic-abuse-during-covid-19-includesfinancial-and-online-abuse.> [Diakses 8 Juli 2021].

Bruneau, C., 2018. How do patriarchy and capitalism jointly reinforce the oppression of women? - CADTM. [daring] CADTM. Dapat diakses di: <https://www.cadtm.org/How-dopatriarchy-and-capitalism-jointly-reinforce-the-oppression-of-women $>$ [Diakses 3 Maret 2021].

CNN Indonesia, 2021. Sejarah Hari Perempuan Internasional yang Dirayakan 8 Maret. [daring] CNN Indonesia. Dapat diakses di: <https:/www.cnnindonesia.com/gayahidup/20210308072643-284-614886/sejarah-hari-perempuan-internasional-yangdirayakan-8-maret> [Diakses 3 Maret 2021].

UN Women, 2021. The Shadow Pandemic: Violence against women during COVID-19. [daring] UN Women. Dapat diakses di: <https://www.unwomen.org/en/news/in-focus/in-focusgender-equality-in-covid-19-response/violence-against-women-during-covid-19> [Diakses 1 April 2021].

World Bank, 2019. Development Marketplace: Innovations to Address Gender Based Violence. [daring] World Bank Live. Dapat diakses di: < https://live.worldbank.org/developmentmarketplace-gender-based-violence $>$ [Diakses 1 April 2021].

Artikel Jurnal

Bataka, H., 2020. Globalization and Gender Inequalities in Sub-Saharan Africa. The International Trade Journal, 34(6), pp.516-534.

Burris, V., 1982. The dialectic of women's oppression: Notes on the relation between capitalism and patriarchy. Berkeley Journal of Sociology, 27, pp.51-74.

Brouwers, L. and Herrmann, T., 2020. "We Have Advised Sex Workers to Simply Choose Other Options"- The Response of Adult Service Websites to COVID-19. Social Sciences, 9(10), p.181.

Coxen, J., Castro, V., Carr, B., Bredin, G. and Guikema, S., 2021. COVID-19 pandemic's impact on online sex advertising and sex trafficking.

Cruz, K., 2018. Beyond liberalism: Marxist feminism, migrant sex work, and labour unfreedom. Feminist Legal Studies, 26(1), pp.65-92.

Gerring, J., 2004. What is a case study and what is it good for?. American political science review, 98(2), pp.341-354.

Rico, M.N., 1997. Gender-Based Violence: A human rights issue.

Stefano, C.D., 2014. Marxist feminism. The encyclopedia of political thought, pp.2305-2310. 
Suzor, N., Dragiewicz, M., Harris, B., Gillett, R., Burgess, J. and Van Geelen, T., 2019. Human Rights by Design: The Responsibilities of Social Media Platforms to Address Gender-Based Violence Online. Policy \& Internet, 11(1), pp.84-103.

Wisman, J.D., 2014. Capitalism and Inequality Re-Examined. Department of Economics.

Von Werlhof, C., 2007. No critique of capitalism without a critique of patriarchy! Why the left is no alternative. Capitalism Nature Socialism, 18(1), pp.13-27.

Audio

Patel, R., Philpott, T. \& Mclnroy, R, 2015. Bananas: Cynthia Enloe (Ep. 3). [podcast] The Secret Ingredient. Dapat diakses di: <http://spotify:episode:2DEIOwJYfXvTlODmjnVnBW> [Diaskes 1 April 2021].

Buku

Enloe, C., 2014. Bananas, beaches and bases. University of California Press.

Engels, F., 1978. The origin of the family, private property, and the state. New York University Press.

Lukács, G., 1972. History and class consciousness: Studies in Marxist dialectics. mit Press.

Marx, K., 1976. Capital: A critique of political economy. Vol. III.

Williams, C.C., 2005. A commodified world: Mapping the limits of capitalism. Zed Books. 